\title{
УДК: 811.111:378.147
}

DOI: $10.15587 / 2519-4984.2019 .185660$

\section{ПРОСКТНА МЕТОДИКА АНГЛОМОВНОГО ПИСЬМА МАЙБУТНІХ ФАХІВЦІВ 3 АНГЛІЙСЬКОЇ МОВИ: ТЕОРЕТИЧНІ ЗАСАДИ ТА ПРАКТИЧНІ ПРИНЦИПИ}

\section{С. Д. Сторожук}

Проаналізувавши роботи зарубіжних і вітчизняних учених, присвячених проблемам навчання англомовного письма, ми прийшли до висновку, щьо навчанню англомовного академічного письма приділяється недостатньо уваги на мовних курсах у закладах вищої освіти і йому бракує ефективності та інтенсивності внаслідок нерозробленості відповідних навчальних технологій. Представлене дослідження ставить за мету заповнити изю прогалину $і$ запропонувати розроблену ефективну і інтенсивну методику навчання англійської мови в українських 3ВО, де готують фахівців з англійської мови засобами проєктних технологій. Для ичього виникла необхідність сформулювати принципи навчання англомовного письма через використання проєктних технологій та дати аналіз створеної методики навчання іншомовного (англомовного) письма на прикладі розроблених принциипів, на яких базується ї̈ практична реалізація. В статті проаналізовано впровадження проєктних технологій у навчанні письма при підготовці майбутніх викладачів англійської мови, а також представлено розроблені головні та підпорядковані методичні принцчипи, за якими проводиться процес проєктування. В результаті, ми прийшли до висновку, щзо впровадження проєктних технологій у навчанні письма на II та III курсах підготовки майбутніх викладачів англійської мови має базуватися на трьох головних $і$ десяти підпорядкованих спеціальних методичних принципах, які забезпечують його організаційні засади, самостійність виконання студентами проєктної роботи та оптимізацію навчання іншомовного письма

Ключові слова: 3ВО, іншомовне (англомовне) письмо, проєктні технологї, проєктна робота, методичні принщипи

Copyright (C) 2019, S. Storozhuk. This is an open access article under the CC BY license (http://creativecommons.org/licenses/by/4.0).

\section{1. Вступ}

Необхідність якомога широкого, інтенсивного та ефективного навчання англомовного письма була вже давно усвідомлена зарубіжними вченими в галузі методики викладання англійської мови, що обумовило появу численних дослідницьких публікацій $[1,2]$. Ще більше існує підручників, що видані в англомовних країнах і спеціально створені для навчання англомовного письма. Інтенсивна, багатогранна і багаторічна теоретична і практична робота в галузі навчання англомовного письма дозволила створити інноваційні підходи до цього навчання, такі як процесуальний Вони підняли навчання англомовної писемної комунікації на значно вищий рівень.

\section{2. Літературний огляд}

Необхідність та актуальність проведеного дослідження пов'язана 3 тим, що формування англомовної комунікативної компетентності у письмі, якого десятиріччями в мовних вишах України навчали явно недостатньо, все більше виходить на передній план наукових досліджень 3 методики навчання англійської мови [3] і стає одним з головних завдань підготовки майбутніх викладачів англійської мови. Це обумовлено потребами суспільства, в якому писемна англомовна комунікація починає займати все більше місце, так що викладачі англійської мови повинні якомога ефективніше іiі навчати, що неможливо, якщо вони самі не володіють такою комунікацією на високому рівні.

Особливо важливо в цьому плані навчити майбутніх викладачів англомовного академічного пись- ма, в першу чергу, написання англомовних академічних есе як основи для оволодіння ними мовленнєвими навичками та вміннями в усіх творчих видах письма, таких як написання статей, звітів тощо. Нажаль, такому навчанню приділяється явно недостатньо уваги у вишівських мовних курсах і йому бракує ефективності та інтенсивності внаслідок нерозробленості відповідних навчальних технологій.

Не меншою перешкодою для цієї ефективності та інтенсифікації є факт відсутності спроб поєднати (i науково обгрунтувати це поєднання) навчання англомовного письма 3 найновішими технологіями, що активізують, інтенсифікують та оптимізують опанування іншомовних мовленнєвих навичок та вмінь. Однією з таких технологій є технологія навчального проєктування. Науковці використовують поняття "навчальне проєктування"[4], "проєктна технологія"[5], "метод проєктів"[6]. На думку дидактів, у навчально-виховному процесі має вияв технологія просктування, що передбачає розв'язання якоїнебудь проблеми, яка передбачає, з одного боку, використання різноманітних методів, засобів навчання, а 3 другого - інтегрування знань, умінь 3 різних галузей науки, техніки, творчості $[7,8]$. Автори наголошують, що результати виконання проєктів повинні бути “відчутними”: якщо розв'язувалася теоретична проблема, то має бути знайдене іï конкретне вирішення, якщо практична - певний результат, готовий до впровадження. Окрім цього, зазначають дослідники, навчальне проєктування орієнтоване, перш за все, на самостійну - індивідуальну, парну або групову - роботу, яку учні виконують упродовж 
визначеного часу [9]. Тому сутність проєктної технології вчені вбачають у стимулюванні учнів до вирішення певних проблем, що передбачає володіння необхідними знаннями (здобуття їх за необхідності), та на основі проєктної діяльності розв'язання однієї або низки проблем, а також демонстрації практичного застосування здобутих знань і набутих умінь, а мету навчального просктування - у створенні педагогом таких умов освітнього простору, за яких його результатом є індивідуальний досвід проєктної діяльності учня. Тим фактом, що результатом проєктної діяльності тих, хто навчається іноземним мовам, найчастіше $є$ якійсь іншомовний писемний продукт, робить навчальне проєктування в курсі іноземних мов нібито навмисно створеним для інтенсифікації навчання іншомовного письма, особливо письма академічного, типу есе, оскільки продукти навчальних проєктів у мовних курсах найчастіше $є$ близькими за формою та змістом до таких есе. На жаль, ніхто 3 науковців ще не спробував інтенсифікувати та оптимізувати навчання англомовного академічного письма у мовних закладах вищої освіти через впровадження проєктних технологій у це навчання.

\section{3. Мета та задачі дослідження}

Мета дослідження - удосконалити та якомога інтенсифікувати навчання англомовного письма майбутніх фахівців 3 англійської мови, використовуючи для цього найновіші навчальні технології, спеціально створені для інтенсифікації та оптимізації мовної підготовки.

Для досягнення мети були поставлені такі здачі:

1. Сформулювати принципи навчання англомовного письма через використання проєктних технологій.

2. Дати аналіз усіх головних та підпорядкованих принципів навчання іншомовного/англомовного письма та описати ефективність їх використання в процесі навчання академічного письма за допомогою проєктних технологій.

\section{4. Система методичних принципів у на- вчанні іншомовного письма}

Кожний навчальний процес, у тому числі і процес формування писемної комунікативної компетентності майбутніх викладачів англійської мови на основі проєктних технологій, будується на базі певних принципів.

Самі такі принципи регулюють використання тих чи інших специфічних методик або технологій навчання, тому різні автори пропонують свою систему спеціальних принципів. Вона потрібна і для розробки проєктної технології навчання іншомовного (англомовного) письма (ІАП) у ЗВО і тому була запропонована нами як основа для створення цієї практичної технології.

Впровадження проєктних технологій у навчанні письма майбутніх викладачів англійської мови має базуватися на трьох головних і десяти підпорядкованих спеціальних методичних принципах, за якими має проводитися увесь процес проєктування і які забезпечують його організаційні засади, самостій- ність виконання студентами проєктної роботи та оптимізацію навчання іншомовного письма.

\section{5. Результати дослідження}

Першим і центральним з головних принципів, що були висунуті, став приничип демократизації процесу навчання англомовного письма з використанням проєктних технологій (принцип демократизаціï). Другим провідним принципом був принциип підвищеного рівню автономії навчальної діяльності студентів у процесі використання проєктних технологій для навчання англомовного письма (принщии підвищеного рівня автономії). Нарешті, третім принципом став принцип удосконалення навчання англомовного письма через використання проєктних технологій/проєктної роботи (принцип удосконалення навчання письма через проєктну роботу). Кожен з названих провідних/головних спеціальних принципів має підсистему підпорядкованих принципів i пов'язаний прямими і зворотними зв'язками з іншими провідними принципами. Вся система принципів заслуговує на детальний розгляд.

Приниии демократизаиії передбачає, що в процесі виконання проєктної роботи студенти фактично беруть на себе управління власним навчальним процесом, тобто через демократичне обговорення самі вирішують, якими мають бути конкретні завдання учасників проєкту, як розподіляти ці завдання між ними, які результати мають бути досягнутими і в які терміни, самі обговорюють та оцінюють ці результати тощо, тобто самі, на суто демократичних засадах, керують власною навчальною діяльністю відразу після видачі викладачем загального проєктного завдання усій групі учасників проєкту і до моменту остаточного оцінювання ним кінцевого результату та матеріального продукту проєктної роботи.

Важко навіть переоцінити значення цього принципу для реалізації переваг проєктної технології. По-перше, він забезпечує підгрунтя для розвитку навчальної автономії тих, хто навчаються, тобто для розвитку їх навчальної самостійності, а також для формування умінь організовувати власну роботу і роботу інших людей не тільки у навчанні, а і взагалі у житті та праці. Це, у свою чергу, розвиває здатність студентів ефективно працювати як у команді, так і індивідуально (виконуючи індивідуальні проєктні завдання). Аналогічним чином, формуються уміння звітувати про проведену роботу як в усній, так і у письмовій формі, оцінювати роботу інших членів команди, об'єктивно знаходити в ній переваги та недоліки. Важливо, що в умовах проєктної роботи успіх діяльності групи цілком залежить від успіху діяльності кожного учасника, своєчасності виконання ним індивідуальних завдань тощо. Тому, завдяки демократичним засадам, на яких будується проєктна робота, коли всі учасники проєкту спільно керують перебігом цієї роботи, забезпечується виховання відповідальності і академічної доброчесності. Названі якості, що виховуються, стосуються спочатку взаємин зі своїми товаришами-одногрупниками, які беруть участь у навчальному проєкті, а надалі вони переносяться на взаємини 3 викладачем та іншими людьми. 
По-друге, демократичність в організації проєктної роботи, в якій постійно потрібно оцінювати роботу інших, розвиває критичне мислення [10]. Крім того, при демократичності побудови процесу проєктування учасникам у цьому процесі постійно приходиться цілком самостійно, не спираючись на підказки та допомогу викладача, знаходити відповіді на незвичні та нестандартні питання. Це, безумовно (і дуже інтенсивно), розвиває творче мислення і творчі підходи студентів до виконання навчальних завдань.

По-третє, саме демократичний характер організації процесу проєктування забезпечує і робить неминучою постійну взаємодію студентів один $з$ одним у цьому процесі, а також їх постійну взаємодопомогу та взаємонавчання, коли кожен студент обмінюється тим, що знає тільки він, з іншими членами проєктної групи i, у свою чергу, отримує від них інформацію про те, що було невідомо йому в плані реалізації проєкту, який виконується. А це робить роботу над проєктом кооперативною з усіма перевагами кооперативного навчання, які розглянуті в літературі, головним серед яких $є$ не просто забезпечення всебічної інтерактивності студентів у навчальному процесі, а й забезпечення їх взаємонавчання у цьому процесі.

Всі перелічені якості, здатності та уміння студентів формуються через виучувану мову, а, в кінцевому результаті, переростають в їх загальнолюдські якості, здатності та вміння, що не залежать від мови. Це $є$ мабуть найціннішим наслідком реалізації принципу демократизації.

Другий 3 головних принципів впровадження проєктних технологій у навчання іншомовного (англомовного) письма є принциип підвищеного рівня навчальної автономії. Він, з одного боку, дуже тісно пов'язаний 3 центральним 3 провідних принципів демократизації, так що можна було б навіть сказати, що автономія витікає з демократизації і сама, в свою чергу, сприяє цій демократизації. Але, з іншого боку, в демократично організованому навчальному процеci, хоча деяка навчальна автономія обов'язково буде мати місце, вона може бути досить обмеженою, тобто суто викладацькі функції залишаться за викладачем і жодна 3 них не перейде до тих, хто навчаються. У навчальному процесі, що побудований на базі проєктних технологій, навпаки, навчальна автономія студентів буде значно ширшою (підвищений рівень автономії), охоплюючи, за рахунок само- і взаємоконтролю, і деякі контролюючі функції викладача. Тому їі доцільно трактувати як окремий провідний/головний принцип впровадження досліджуваних технологій.

Принцип підвищеного рівня навчальної автономії передбачає, що весь перебіг проєктної навчальної діяльності, визначення її конкретних цілей, бажаних результатів, етапів проведення тощо, виконання усіх навчальних дій, обговорення та звітування про їх результати здійснюється тими, хто навчаються цілком самостійно і через самоконтроль та взаємоконтроль, а контроль з боку викладача настільки завуальований, що $є$ майже непомітним. Це не означає, що викладач повністю втрачає цей контроль. Як вже було сказано, він видає загальну інструкцію перед початком ПР студентів, окреслює ії кінцеву мету і кін- цевий результат, який потрібно отримати, а також кінцевий термін виконання. Коли цей термін сплив, він проводить разом 3 проєктною групою кінцеве обговорення (звіт) виконаної роботи і досягнутих результатів. Але, коли проєктна робота виконується за умов дистаниіювання викладача, як це зазвичай відбувається у викладанні іноземних мов, перебіг цієї роботи він ніяк відкрито не контролює, а лише уважно спостерігає за нею (звичайно, це не стосується випадків, коли проєктна навчальна діяльність студентів знаходиться під загрозою зриву).

Мета такого спостереження - виконувати для студентів роль не адміністратора, а «фасілітатора» (facilitator [11]) навчального процесу. Функції фасіліmатора полягають у наданні студентам всілякої допомоги та підказок в їх самостійній навчальній діяльності, але лише тоді, коли вони по таку допомогу звертаються і ї̈ потребують з їх власної точки зору.

3 наведеного трактування принципу підвищеного рівня навчальної автономії видна його відмінність від дуже близького та спорідненого 3 ним принципу демократизації. Останній вимагає, щоб студенти самі керували власним навчальним процесом у ході перебігу проєктної роботи, і таке самокерування забезпечує виховання та розвиток їх особистісних якостей та вмінь, взаємонавчання тощо (див. аналіз принципу демократизації та двох підпорядкованих йому принципів вище). Принцип підвищеного рівня автономії окреслює практичний механізм реалізації цього самокерування - через самостійну організаційну та самостійну навчальну діяльність студентів, як групову, так і індивідуальну. Таким чином, два названих принципи пов'язані як прямими, так і зворотними зв'язками.

Розвитку підвищеного рівня навчальної автономії студентів у проєктній роботі допомагає функціонування чотирьох підпорядкованих принципів:

1) принципу самостійного виявлення студентами жанрових та мовних особливостей написання різних писемних документів англійською мовою (принципу самостійного виявлення жанрових та мовних особливостей);

2) принципу інтенсивного використання Інтернет-пошуку для самостійного виявлення студентами жанрових та мовних особливостей написання різних писемних документів англійською мовою (принципу інтенсивного використання Інтернет-пошуку);

3) принципу групового обговорення та опрацювання індивідуально виявлених жанрових та мовних особливостей написання різних писемних документів англійською мовою (принципу групового обговорення та опрацювання);

4) принципу сполучання індивідуального виконання письмових робіт, пов'язаних зі змістом проєкту, 3 їх груповим та парним взаємообговоренням та взаємокоментуванням (принципу сполучання індивідуального виконання письмових робіт з їх груповим та парним взаємообговоренням та взаємокоментуванням).

Сам принцип підвищеного рівня навчальної автономії разом 3 чотирма підпорядкованими йому принципами складають підсистему принципів забезпечення самостійності виконання студентами проєктної роботи. 
Чотири підпорядкованих принципи, які входять до цієї підсистеми, заслуговують на окремий короткий розгляд.

Перший з них, принцип самостійного виявлення жанрових та мовних особливостей, передбачає, що всі жанрові та мовні особливості писемних текстів, які студенти мають навчитися писати, вони повинні виявити самі через власну пошукову роботу. Таке самостійне знаходження навчальної інформації через інтенсивний власний пошук є однією 3 головних переваг проєктних технологій.

Але практична реалізація розглянутого принципу можлива лише в умовах, коли самостійна пошукова робота студентів здійснюється через мережу Інтернету (принцип інтенсивного використання Інтернет-пошуку), інакше їм просто не буде звідки взяти достатню кількість зразків для жанрового та текстового аналізу i, взагалі, усю необхідну жанрову та текстову інформацію. Принциип інтенсивного використання Інтернет-пошуку є настільки самоочевидним, що його подальша деталізація навряд чи потрібна.

Що стосується третього принщипу групового обговорення та опрацюювання, то він також є самоочевидним. Самостійне виявлення студентами жанрових та мовних особливостей тих чи інших писемних текстів через Інтернет-пошук $є$ типовим індивідуальним завданням у процесі ПР. Кожне таке індивідуальне завдання може виконувати один або (найчастіше) декілька студентів у групі, але в будь-якому випадку це буде суто індивідуальна робота кожного 3 тих, хто навчаються. Коли така робота виконана, результати кожної з індивідуальних робіт повинні стати надбанням кожного $з$ учасників проєкту, так щоб вони могли використовувати їх у подальшій проєктній роботі. А для цього результати мають бути обговорені групою, тобто опрацьовані у такому загальногруповому обговоренні або в обговоренні у малих групах, щоб забезпечити засвоєння індивідуально надбаних результатів кожним членом групи. Практично це означає, що студенти, які проводили індивідуальний пошук, звітують групі про результати свого пошуку, після чого група колективно їх аналізує, приходячи до спільних висновків, як, 3 точки зору жанрових та мовних особливостей, мають бути побудовані тексти того чи іншого жанру. В ході групового аналізу виявляються і недоліки індивідуальної роботи студентів, які звітують, знаходяться шляхи ліквідації цих недоліків, а також коментується успішність індивідуальної роботи (взаємооцінювання).

Останній 3 названих чотирьох принципів- це принции сполучання індивідуального виконання письмових робіт з їх груповим та парним взаємообговоренням та взаємокоментуванням. Цей принцип стосується не виявлення особливостей написання текстів різних жанрів (див. три попередніх принципи), а самому такому написанню. В його межах письмові роботи пишуться тими, хто навчаються, індивідуально, але кожна 3 них аналізується та коментується іншими студентами 3 метою удосконалення. Саме виконання цієї вимоги забезпечується названим принципом, який одночасно допомагає реалізувати як індивідуальну, так і групову автономію в навчанні письма (див. провідний принцип у підсистемі, що аналізується).
Третій з провідних/головних принципів, висунутих на початку: принциип удосконалення навчання письма через проєктну роботу і підпорядковані йому принципи націлені на формування у студентів головним чином мовленнєвих навичок та вмінь, які належать до іншомовної/англомовної комунікативної компетентності (ІАКК) в письмі.

Підпорядкованими принципу удосконалення навчання письма через проєктну роботу принципами $є$ :

1) принцип відбору змісту навчання письма в проєктній роботі у строгій відповідності до складових ІАКК у письмі та до тих мовних і позамовних особливостей англомовного письма, що відрізняють його від письма рідною мовою (відбір змісту навчання у відповідності до складових ІАКК і особливостей англомовного письма);

2) принцип поступового підвищення якості чорнових варіантів письмових робіт студентів, слідуючи процесуальній методиці навчання письма (принцип поступового підвищення якості письмових робіт студентів);

3) принцип виконання студентами письмових робіт в основному через використання текстового редактору (принцип використання текстового редактору);

4) принцип оприлюднення та публічного оцінювання писемних результатів ПР студентів через мережу Інтернету (принцип оприлюднення результатів через Інтернет).

Перший з цих підпорядкованих принципів (вiдбір змісту навчання у відповідності до складових IAKK $i$ особливостей ІАП) вимагає, щоб добраний для навчального проєкту зміст навчання письма відображав: 1) усі складові ІАКК в письмі (лінгвістичну, соціокультурну, прагматичну, предметну, формально-логічну та паралінгвістичні компетенції); 2) особливості, як мовні, так і позамовні (формат, структурування, особливості викладення змісту та формально-логічних зв'язків у ньому) того жанру письма, якого навчають (написання академічних есе в нашому випадку); 3) особливості стилю/регістру в тому жанрі письма, якого навчають.

Приниип поступового підвищення якості письмових робіт студентів вимагає слідування настановам процесуального підходу в навчанні письма, тобто написання кожної з письмових робіт у декількох чорнових варіантах, так що кожен наступний 3 них сам пишучий удосконалює у порівнянні з попереднім. Цей принцип діє у найтіснішому зв'язку з одним з принципів підсистеми забезпечення самостійності виконання студентами проєктної роботи, а саме з принципом сполучання індивідуального виконання письмових робіт з ї груповим та парним взаємообговоренням та взаємокоментуванням. На основі такого взаємообговорення та взаємокоментування і відбувається удосконалення кожним пишучим кожного $з$ чорнових варіантів своєї письмової роботи.

Приниии використання текстового редакто$p y$, як ясно з самої його назви, передбачає, що письмові роботи студенти здебільшого виконують на комп'ютері. Це дуже важливо, враховуючи, що ті, хто навчаються, самостійно удосконалюють, виправляють і редагують свої письмові тексти, які ними 
пишуться, як то витікає із вимог процесуального підходу взагалі і вимог тих двох принципів, які були обговорені у попередньому абзаці. Текстовий редактор дуже допомагає у такому самовдосконаленні, самовиправленні і саморедагуванні написаних текстів і відмовлятися від такої ефективної допомоги, особливо на початкових етапах ПР 3 навчання англомовного академічного письма, в ніякому разі не можливо.

Нарешті, останній принцип оприлюднення результатів ПР через Інтернет є хіба не найважливішим 3 підпорядкованих принципів підсистеми, яка розглядається і яка може бути названою підсистемою забезпечення оптимізації навчання іншомовного письма. Письмо є таким видом мовленнєвої діяльності, який обов'язково потребує читачів написаних текстів, причому читачів незалежних, а не викладачів, зобов'язаних за посадою читати те, що написали студенти [12]. Якщо таких незалежних читачів немає, то у тих, хто навчаються, зникає мотивація до письма іноземною мовою $і$ навчання його. Тому в підсистемі забезпечення оптимізаиії навчання іншомовного письма, яка націлена на краще оволодіння студентами навичками та вміннями ІАП, оприлюднення письмових результатів виконання проєктів $\epsilon$ вкрай важливим 3 точки зору забезпечення позитивної навчальної мотивації. А Інтернет $є$ найкращим засобом такого оприлюднення.

\section{6. Висновки}

1. Впроваджуючи проєктування у навчання англомовного письма для підготовки майбутніх фахівців 3 англійської мови, необхідно спиратися на ряд принципів використання таких технологій:

- демократизації;

- підвищеного рівня навчальної автономії;

- удосконалення навчання іншомовного письма через ПР;
- виховного та розвиваючого впливу проєктної навчальної діяльності;

- кооперативної навчальної діяльності у проєктній роботі для забезпечення взаємонавчання студентів;

- самостійного виявлення жанрових та мовних особливостей; пошуку;

- інтенсивного використання Інтернет-

- групового обговорення та опрацювання особливостей письма у певних жанрах;

- сполучання індивідуального виконання письмових робіт з їх груповим та парним взаємообговоренням та взаємокоментуванням;

- відбору змісту навчання у відповідності до складових ІАКК і особливостей ІАП;

- поступового підвищення якості письмових робіт студентів;

- використання текстового редактора;

- оприлюднення результатів ПР через Інтернет.

2. Проведений аналіз головних та підпорядкованих принципів навчання ІАП за допомогою проєктних технологій наочно продемонстрував, наскільки повно вони охоплюють усі особливості використання таких технологій, відповідають усім особливостям ІАП як виду іншомовної мовленнєвих діяльності, якому потрібно навчити студентів-майбутніх викладачів. Він також показав, наскільки повно і органічно запропонована система принципів відображає i включає у себе найновіші досягнення методики навчання іншомовного письма як виду іншомовної мовленнєвої діяльності. Таким чином, можна розглядати запропоновану систему принципів як практичне втілення тих теоретичних положень і постулатів для формування писемної комунікативної компетентності майбутніх викладачів англійської мови на основі проєктних технологій.

\section{Література}

1. Byrne D. Teaching writing skills. London: Longman, 1988. 154 p.

2. Tribble C. Writing. Oxford: Oxford University Press, 1996. 174 p.

3. Жовнич О. В. Методика навчання професійно орієнтованого англомовного писемного спілкування майбутніх журналістів засобами блогтехнологій: дис. ... канд. пед. наук. Київ, 2018. 260 с.

4. Tarnopolsky O. The scale of learner autonomy: Three levels in an intensive English program // Independence. 2001. Issue 29. P. 2-5.

5. Тітова В. В. Модульно-проектна методика навчання англійської мови студентів вищих технічних закладів освіти: дис. ...канд. пед. наук. Київ, 2001. 268 с.

6. Купрікова С. В. Шляхи реалізації проектної методики при навчанні іноземної мови // Педагогічні науки: теорія, історія, інноваційні технології. 2013. № 4 (30). С. 223-230.

7. Медведева Л. И. Проектная методика обучения иностранному языкув контексте современных педагогических технологий // Наукові записки. Серія: Педагогіка. 2011. № 4. С. 129-133.

8. Устименко О. М. Проектна технологія навчання іноземних мов і культур студентів мовних вищих навчальних закладів // Іноземні мови. 2017. № 2. С. 44-58.

9. Освітні технології: навч.-метод. пос. / Пехота О. М., Кіктенко А. З., Любарська О. М. та ін.; ред. Пехота О. М. Київ: АСК, 2002. 255 c.

10. Freire P. Education for Critical Consciousness. London: Bloomsbury Academic, 2013. 168 p.

11. Rogers C. R. Freedom to learn for the 80s. Columbus: Charles E. Merrill Publishing Company, 1983. 312 p.

12. Тарнопольский О. Б., Кожушко С. П. Методика навчання студентів вищих навчальних закладів письма англійською мовою. Вінниця: Нова книга, 2008. 288 с.

Сторожук Світлана Дмитрівна, старший викладач, кафедра прикладної лінгвістики та методики навчання іноземних мов ,Університет імені Альфреда Нобеля, вул. Січеславська Набережна, 18, м. Дніпро, Україна, 49000, E-mail: rebit2006@ukr.net 